\title{
Project-Based Approach in Training Business Lawyers for Digital Economy Through the Prism of Goal Setting
}

\author{
Inna Vladimirovna Ershova ${ }^{1 *}$, Ekaterina Evgenievna Enkova $^{1}$, Anatoly Nikolaevich \\ Levushkin $^{1}$ and Kama Klimentievna Dzhindzholiya ${ }^{2,3}$ \\ ${ }^{1}$ Kutafin Moscow State Law University (MSAL), Department of Business and Corporate Law, \\ Moscow, Russia \\ ${ }^{2}$ Abkhaz State University, Department of Civil Law and Procedure, Sukhum, The Republic of \\ Abkhazia \\ ${ }^{3}$ Arbitration Court of the Republic of Abkhazia, Sukhum, The Republic of Abkhazia
}

\begin{abstract}
The goal of the study is to determine the fundamental intention of the educational project implementation in the Masters' program for training business lawyers for the digital economy. The main methods used are the analysis method and the sociological method. The main result of the study is that the main goal of educational projects for training business lawyers is the development of a set of regulatory competences. The conclusions are that the competence-based approach is an objective trend in modern education, largely supported by students. A number of factors have been identified that impede the formation of basic lawyers' competences for students in the digital economy, based on the sociological study. Due to the lack of reference to "digital" competences in federal state educational standards, it is advisable to introduce additional competences in the local acts of the educational organization that take into account the need for lawyers to use information and telecommunication technologies.
\end{abstract}

\section{Introduction}

The lawyers for the business sector are currently being trained on the basis of a complex system that can be generally described as an educational project. The word "project" originates from the Latin projectus - conception, idea, image, intention, rationale, or plan. Project management in the most common version is interpreted as the activity (a set of functions and actions) for managing projects [1]. It is obvious that the management of an educational project for training business lawyers involves the determination of the goals and terms of the project, the formation of the resource provision, and the precise coordination of the actions of participants, both educators and students. This range of problems invariably causes great interest among researchers, which is confirmed in the scientometric review of global research in project management [2]. Moreover, researchers can use some literature research methods that have been developed in the project management science and contribute

* Corresponding author: inna.ershova@mail.ru 
to the development of competences for making managerial decisions [3], analysis of bibliometric mapping [4], and visualization of bibliometric tools [5].

It is impossible to highlight all the components in detail within this publication, and therefore, the authors define and describe the fundamental goal of implementing educational projects for training business lawyers for the digital economy. At the same time, they express some disagreement with representatives of the nascent "new project management" movement, which proclaims the backwardness of traditional methods of project administration, where the management principles by objectives dominate [6].

\section{Methods}

The study is based on the following methods of scientific knowledge: analysis, synthesis, deduction, classification, interpretation, forecasting, as well as comparative and sociological methods. In particular, 65 students of the Masters' program "Legal Support for Business (Business Lawyer)" at the Kutafin Moscow State Law University (MSAL) were surveyed in the course of the sociological study "Competence-based approach to learning" conducted by the authors in 2019. The authors also conducted a sociological survey "Digitalization of the educational process" in 2020, using the questionnaire method, where 121 bachelors and 44 masters from the "Business Lawyer" program were the respondents in the targeted sample.

\section{Results}

\subsection{Mastering competences as the main goal of educational projects for training business lawyers}

The projects for training business lawyers in modern higher education in Russia are implemented mainly as specialized Masters' programs. It is very important to properly build a portfolio of projects with the products that will be in demand by the market. The authors are convinced that the tools used in other areas of public relations can also be used in educational management $[7,8]$. For example, a significant number of successful educational projects are being implemented at the Kutafin Moscow State Law University (MSAL), including the Masters' program "Business Lawyer". According to one of the classifications of management projects, the project under consideration can be classified as mature, which determines the specifics of management. The balance of ensuring sustainability and innovation-driven growth is important in order to avoid stagnation and loss of attractiveness [9]. This predetermined a regular update of the range of problems under study and saturation of the program with problematic aspects (in particular, the development of small [10] and family [11] entrepreneurship) and innovations (the legal regime of self-employment [12] and the clustering of the Russian economy [13] are vivid examples). The problem of transformation in training business lawyers was particularly acute during the transition to the digital economy [14], which necessitated the updating of the educational project.

The following other conditions determine the success of the Masters' program "Business Lawyer": integrated content; interdepartmental and interdisciplinary approach; Masters' students being coauthors in the educational process, profiling; using active and interactive forms of classes; availability of special educational literature; involvement of practicing lawyers in teaching; and Masters' dissertations being practice-oriented projects.

The Masters are currently trained on the basis of the Federal State Educational Standard of Higher Professional Education in major 40.04.01 Law ("Master" qualification (degree)), approved by Order of the Ministry of Education and Science of Russia No. 1763 dated 
December 14, 2010 (hereinafter - the FSES). Mandatory FSES for the development of the competences of lawyers are reflected in educational programs.

As such, the implementation and management of the Masters' program "Business Lawyer" and other educational programs are aimed at the competences as the main goal. The problems of the formation and development of basic competences of lawyers for the business sector become especially relevant in the context of building a digital economy in Russia.

The concept of competences and the competence-based approach have been studied in detail by representatives of pedagogical science $[15,16,17,18]$.

The theory proposes a definition of "competences" as some internal, potential, hidden psychological innovations (knowledge, ideas, programs... actions, value systems, and relationships), which are later revealed in the person's competences as relevant and active manifestations [15, p. 23].

The interpretation of the term provided in the Glossary of the TUNING European project (http://www.unideusto.org/tuningeu) is of interest in terms of application. The competences are defined as a dynamic combination of cognitive and metacognitive skills, knowledge, understanding, ethical values, as well as interpersonal, intellectual, and practical skills.

The competences were classified by foreign researchers [19], and their classification by foreign and Russian educational models was presented in the work of D.I. Ivanov [16, pp. 9 $-18]$. TUNING proposes the division of competences into subject-specific and common for all academic qualifications. The FSES for the Masters' program classifies competences into general cultural and professional for the educational purposes. However, it does not contain competences that meet the needs of the digital economy.

The current national program "Digital Economy of the Russian Federation" (passport approved by the Presidium of the Presidential Council for Strategic Development and National Projects, minutes No. 16 dated December 24, 2018) as part of the federal project "Personnel for the Digital Economy" (approved by the Presidium of the Government Commission for Digital Development and Using Information Technology to Improve the Quality of Life and Conditions for Business Activities, minutes No. 9 dated May 28, 2019) provides education on the development of competences in the digital economy. The important aspect is that 270 thousand working specialists should be trained in the competences in the digital economy by the time the program is completed (December 31, 2024).

The list of key competences in the digital economy was approved by order of the Ministry of Economic Development of Russia No. 41 dated January 24, 2020. These competences include communication and cooperation in the digital environment; self-development in conditions of uncertainty; creative thinking; information and data management; and critical thinking in the digital environment. It is obvious that they belong to soft skills - the category of general competences.

\subsection{Goal of educational projects through the prism of sociological studies}

The urgency of the range of problems under study gave rise to a desire to find out the position of students. It must be noted that the method of quantitative assessment of the teaching quality at the university, where students and teachers become not just participants but also project managers, is actively used in education [20,21].

In the course of the sociological study "Competence-based approach to learning" (2019) [22], more than half $(53.8 \%)$ of the respondents gave a positive assessment of the competencebased approach, $18.4 \%$ of the respondents said they had not been aware of it but wanted to understand what it had been, and more than a quarter of the respondents $(27.7 \%)$ qualified the approach under study only as a formal requirement of educational standards. 
As was already mentioned in the Methods section, the authors of the article conducted the sociological study "Digitalization of the educational process". The survey results for the positions under study are presented in Table 1.

Table 1. Digitalization of the educational process: basic competences of lawyers

\begin{tabular}{|c|c|c|c|}
\hline $\begin{array}{ll}\text { Question } & \text { Education degree } \\
\end{array}$ & $\begin{array}{l}\text { Bachelor } \\
\text { program } \\
\quad 121\end{array}$ & $\begin{array}{l}\text { Masters' } \\
\text { program } \\
\quad 44\end{array}$ & $\begin{array}{l}\text { Total } \\
165\end{array}$ \\
\hline $\begin{array}{l}\text { 1. Basic competences of lawyers for the digital economy to be } \\
\text { formed as a result of education at a law university are } \\
\text { specified in: } \\
\text { A) strategic planning documents on digitalization (national, state } \\
\text { programs, etc.) } \\
\text { B) FSES } \\
\text { C) local regulations of the university } \\
\text { D) other (specify) }\end{array}$ & $\begin{array}{l}\text { A } 43 \\
\text { B } 69 \\
\text { C } 21 \\
\text { D } 2 \\
\end{array}$ & $\begin{array}{l}\text { A } 8 \\
\text { B } 30 \\
\text { C } 9\end{array}$ & $\begin{array}{l}\text { A } 51 \\
\text { B } 99 \\
\text { C } 30\end{array}$ \\
\hline $\begin{array}{l}\text { 2. Do you know what basic competences of lawyers for the } \\
\text { digital economy are to be formed as a result of education at } \\
\text { a law university? } \\
\text { A) I do } \\
\text { B) I don't } \\
\text { B1) Please provide some examples if you do }\end{array}$ & $\begin{array}{l}\text { A } 97 \\
\text { B } 25 \\
\text { B } 10\end{array}$ & $\begin{array}{l}\text { A } 27 \\
\text { B } 17\end{array}$ & $\begin{array}{l}\text { A } 124 \\
\text { B } 42\end{array}$ \\
\hline $\begin{array}{l}\text { 3. In your opinion, does the current higher education system } \\
\text { allow students to form the basic competences of lawyers for } \\
\text { the digital economy? } \\
\text { A) no } \\
\text { B) yes } \\
\text { C) in part }\end{array}$ & $\begin{array}{l}\text { A } 47 \\
\text { B } 8 \\
\text { C } 69\end{array}$ & $\begin{array}{l}\text { A } 8 \\
\text { B } 6 \\
\text { C } 31\end{array}$ & $\begin{array}{l}\text { A } 55 \\
\text { B } 14 \\
\text { C } 100\end{array}$ \\
\hline $\begin{array}{l}\text { 4. In your opinion, what factors impede the formation of the } \\
\text { basic competences of lawyers for the digital economy in } \\
\text { students? } \\
\text { A) lack of an appropriate material and technical base at a } \\
\text { university } \\
\text { B) inadequate regulatory framework } \\
\text { C) lack of necessary knowledge and skills in teachers } \\
\text { D) indifferent attitude of students to innovations in the } \\
\text { educational process } \\
\text { E) other (indicate) }\end{array}$ & $\begin{array}{l}\text { A } 80 \\
\text { B } 26 \\
\text { C } 47 \\
\text { D } 30 \\
\text { E } 7\end{array}$ & $\begin{array}{l}\text { A } 18 \\
\text { B } 16 \\
\text { C } 11 \\
\text { D } 18 \\
\text { E } 1\end{array}$ & $\begin{array}{l}\text { A } 98 \\
\text { B } 42 \\
\text { C } 58 \\
\text { D } 48 \\
\text { E } 8\end{array}$ \\
\hline
\end{tabular}

\section{Discussion}

As noted above, the FSES of the Masters' program does not provide for the formation of "digital" competences of lawyers.

The "normative" competences can be updated by introducing additional competences in the local regulations of an educational institution, which include the need for lawyers to use information and telecommunication technologies. For example, the wording of some professional competences for the Masters' program should be supplemented by type of professional activity as follows:

law enforcement activity - the ability to apply legal regulation and implement substantive and procedural law in professional activities, including through the use of information and telecommunication networks (PC-2); 
expert advisory activity - the ability to provide qualified legal opinions and advice in specific types of legal activity, including through the use of information and telecommunication technologies (PC-8); and

organizational and managerial activity - the ability to make optimal managerial decisions in the digital environment (PC-9).

The important aspect is that the interaction between the university administrative workers and representatives of specialized departments is necessary in the distribution of competences among the academic disciplines of the basic or variative part of the educational program. This will allow to take into account the specifics of the disciplines and at the same time to ensure that graduates master all the competences specified in the FSES and (or) in the local regulations of the university. The head of the educational project in the form of a Masters' program should play a significant role by masterfully using various project management tools - from full trust to the specialists implementing the project to monitoring it at all stages [23].

\section{Conclusion}

A range of issues related to the implementation of educational projects to train businesses lawyers in the digital age have not yet been adequately covered. The solution of the following tasks is seen as a priority:

- formation of an individual educational trajectory [24], in particular, through the synergy of offline and online education formats and the introduction of the " $2+2+2$ " system announced by the President of the Russian Federation [25];

- development of the project-based education, when a group of students receives a complex multilevel practical task for joint work; and

- development of electronic educational resources in all majors, which include lectures, tests, videos, and hyperlinks.

It must be emphasized that educational projects for business should be in constant development. At the same time, project managers must manage changes, quickly responding to the market needs [26].

The reported study was funded by the RFBR, project No. 18-29-16081 "Transformation of the conceptual framework for the training of lawyers for business in the digital economy".

\section{References}

1. E.V. Savenkova, O.A. Shklyarova, Project management in an educational organization (Moscow State Pedagogical University, Moscow, 2019)

2. R.F. de Toledo, H.L. de Miranda Junior, J.R. Farias Filho, H. Gomes Costa, Data in Brief 25 (2019).

3. F. Treinta, J.R. Farias Filho, A.P. Sant'Anna, L.M. Rabelo, Production 24(3) 508-520 (2014).

4. N.J. Van Eck, L. Waltman, Scientometrics 84(2) 523-538 (2009).

5. N.J. Van Eck, L. Waltman, Visualizing bibliometric networks, In Y. Ding, R. Rousseau, \& D. Wolfram (Eds.), Measuring scholarly impact: Methods and practice (Springer, 2014).

6. R. Picciotto, Int J of Proj M (2019)

7. M. Martinsuo, J. Geraldi, Int J of Proj M (2020).

8. P.J. Stephenson, Perspectives in Ecology and Conservation 17(4), 182-192 (2019)

9. C.T. Cerdeiral, G. Santos, J Of Sys and Software 148, 56-87 (2019) 
10. I.V. Ershova., O.A. Tarasenko, Perm University Herald, Juridical Science 39 99-124 (2018)

11. A.N. Levushkin, P.A. Matveev, G.Yu. Tolstova, I.A. Mitsyk, N.L. Avilova, Int J of Rec Tech and Eng (IJRTE) 8(4) 6085-6088 (2019)

12. I.V. Ershova, E.V. Trofimova, D. Davtyan-Davudova, S.Y. Kochetkova, Computational Intelligence 826, 153-162 (2019)

13. Y.A. Svirin, A.A. Mokhov, I.V. Ershova, L.V. Andreeva, V.A. Gureev, Espacios 39(22) (2018)

14. I.V. Ershova, O.A. Tarasenko, E.E. Enkova, N. Kvitsinia, Studies in Computational Intelligence 826, 145-152 (2019).

15. I.A. Zimnyaya, Key competences as an effective targeted basis of the competence-based approach in education (Research center of problems of specialists training quality, Moscow, 2004).

16. D.I. Ivanov, Competences and competence-based approach in modern education (Moscow, 2007).

17. T.B. Mikheeva, Scientific notes of the Trans-Baikal State Humanitarian and Pedagogical University named after N.G. Chernyshevsky 5(40), 110-114 (2011).

18. A.V. Firer, Omsk Scientific Bulletin 1, 169-172 (2012).

19. J. Winterton, F. Delamare, L. Deist, E. Stringfellow, Typology of knowledge, skills and competences (Office for Official Publications of the European Communities, Luxembourg, 2006)

20. J.D. Cano-Moreno, J.M. Arenas, V. Sánchez, M. Islán, J. Narbón, Procedia Manufacturing 41, 930-937 (2019)

21. I.V. Ershova, The use of the arsenal of empirical sociology in theoretical and applied civil law research. Methodological problems of civil law research (Statute, Moscow, 2018)

22. I.V. Ershova, Method Pr Of Civ Res 2(2) 9-25 (2020)

23. L. Jørgensen, T. Åsgård, Proc Comp Sc 164, 397-406 (2019).

24. I.V. Ershova, O.A. Tarasenko, E.E. Enkova, E.V. Trofimova, Digital Literacy of Lawyers as a Condition of Legal Support for Business in the Digitization Era, in: Popkova E., Sergi B. (eds.) Artificial Intelligence: Anthropogenic Nature vs. Social Origin, ISC Conference, 23 February 2011, Volgograd, Russia (2020)

25. A. Milkus, Minister of Science and Higher Education Valery Falkov - on increasing budget places in regional universities and flexible programs at the university Available at: https://www.kp.ru/daily/27092/4165514/

26. P. Efe, O. Demirors, Computer Standards \& Interfaces 66 (2019). 